\title{
Competence and Commitment: Two Factors that Impact Performance in Organizations

\author{
${ }^{1}$ Paisal Halim, ${ }^{2}$ Natsir, ${ }^{3}$ Syamsiah Badruddin, ${ }^{4}$ Ahmad Hidayat, ${ }^{5}$ Taufan Maulamin \\ ${ }^{1,3}$ Universitas Nasional, Jakarta, Indonesia \\ ${ }^{2}$ Universitas Mathla'ul Anwar, Banten, Indonesia \\ 4,5 Institut Ilmu Sosial dan Manajemen STIAMI, Jakarta, Indonesia \\ Email:paisalhalim@gmail.com,chiah_jurnal2006@yahoo.com,ahmadmangga99@gmail.com,taufanm@gmail.com, \\ nasir100474@gmail.com
}

Received: $19^{\text {th }}$ July 2019, Accepted: 30 ${ }^{\text {th }}$ July 2019, Published: 31 ${ }^{\text {st }}$ August 2019

\begin{abstract}
Outstanding performance is a performance that follows systems according to planned criteria. However, in performance, it must have to have several standards so that efficiency increases so that the company usually runs according to what it wants. To improve employee performance, many factors have an immediate impact on it besides mastering technology and adapting to the global system. The goal of this research is to analyze the impact of competency variables and employee commitment to their performance at work. This study uses a cluster random sampling method with a total sample of 110 respondents. Retrieval of primary data through surveys with questionnaire instruments. In this study compensation indicators are direct and indirect, competency indicators namely: intellectual, emotional and social, indicators of organizational commitment namely affective commitment, commitment continuity, and normative commitment, and performance indicators namely: quality, quantity, timeliness, effectiveness, and independence. The results of this study are the positive and significant influence of competency variables and commitment to employee performance at work. There is a tendency that the two factors are the main factors in improving individual performance better. Significantly there will be an increase in performance if the competencies of employees further enhanced according to today's world technology. Another factor that should be considered is the knowledge factor that will make competence and commitment higher for the organization.
\end{abstract}

\author{
Keywords \\ Companies, Employees, Government, Human Resources, Organizations
}

\section{Introduction}

Human resources, capital, and technology are crucial factors in creating product quality [1]. These sources must be moved effectively to achieve optimal results. To achieve these goals, it is necessary to have a business that is supported by all parties in the organization both from the management and from the employees [2]. In this case, management needs to make breakthroughs to mobilize the human resources they have. The essential resource, among other resources, is human resources because no matter how sophisticated the technology used, it is useless without the support of reliable human resources. Therefore, human resources need to manage carefully [3]. Human resources in the company have roles and functions that are very important for achieving company goals. Human resources here cover all human beings in the organization, namely those involved in the company's operational activities from the lowest level to the highest level (top management), although different levels, all elements of human resources have the same role towards achieving or not the company's goals, neglect of one-part results in hampered achievement of company goals [4]. The success or failure of the company in attaining the goals previously set is highly dependent on human resource capabilities [5].

The individual performance of employees strongly influences the success of an organization. Every organization always tries to improve employee performance to achieve goals [6]. Performance is still a problem that is ever faced by management, so management needs to know the factors that affect employee performance [7]. One measure of employee performance is intellectual ability, which is supported by the ability to master, manage themselves, and the ability to build relationships with others [8]. According to Boyatzis's research $[9,10]$, finding the right person in an organization is not easy. That is because organizations need more than just educated people. However, there are psychological factors that underlie the relationship between personality and their organization. These mental factors influence people's abilities in an organization, such as self-regulation, ambition, confidence, emotions, and peace of mind without being overwhelmed by excitement [11].

Competence related to the role of human resources in an organization or company has the same meaning as the work itself, given the importance of the role of Human Resources in organizations or cooperatives, in this case, human resources as a determinant of organization or company, competency becomes a decisive aspect the success of an organization or company. With high competencies possessed by human resources in an organization or company, of course, this will determine the quality of human resources owned, which will ultimately determine the competitive quality of the company itself. The concept of competency is not something new. According to Spencer and Spencer [12], competence is a characteristic that underlies a person and is related to the effectiveness of individual performance in his work. 
Organizational dedication is not only related to the level of entry and exit of workers but also to the level of sacrificial readiness by workers for the organization [13]. According to Allen and Meyer [14], organizational loyalty can be interpreted as an emotional bond between people and groups, description, and responsibility, and the desire to remain a member of the organization. The response method provided by an organization may not receive much attention from workers to foster a more loyal character. It is due to concerns that workers will be penalized if they complain. Therefore, the need for high trust and organizational support for employees is essential for each member of the organization [15]. Strong commitment can have a positive impact, including improving work performance, work motivation, work period, work productivity, and employees more diligently entering work, thereby reducing absenteeism and reducing turnover [16].

Performance as what done and not done by personnel that affects how much they contribute to the organization, which includes output quantity, output quality, output period, workplace presence, and cooperative attitude [17]. Employee performance in this study seen as having a strong influence on work success. Podsakoff's research [18], found that the ability of employee performance is an aspect of knowledge that significantly determines work success. In turn, from effective work results, employees will be able to get awards from their members in the form of trust. This opinion is clear how the contribution of personnel performance to organizational performance. In turn, from the effective performance results, awards will be obtained from the employees and leaders of the organization in the form of trust [19].

The problem of decreasing the performance of Human Resources employees has investigated by researchers not only associated with competency factors but also several factors or variables of human resource management and organizational behavior and motivation [20]. In this study, several elements of human resource management and organizational behavior that are thought to influence employee performance are compensation, competence, organizational commitment, and job satisfaction. Based on this description and supported by primary and secondary evidence, as well as direct observations of researchers as employees of the Department of Agriculture, it shows that the performance problems of agricultural extension workers within the Department of Agriculture organization need to be studied, especially the influence of existing variables specifically related to improving employee performance such as competence, motivation, leadership, compensation, behavior, and the impact of commitment so that the performance of employees in the agricultural service. The question in this study is whether there is a direct, direct influence of competence and commitment to the performance of agricultural extension staff.

\section{Research Methods}

Research Model: The research model, variables, and indicators can be seen in Figure 1 and Table 1 as follows:

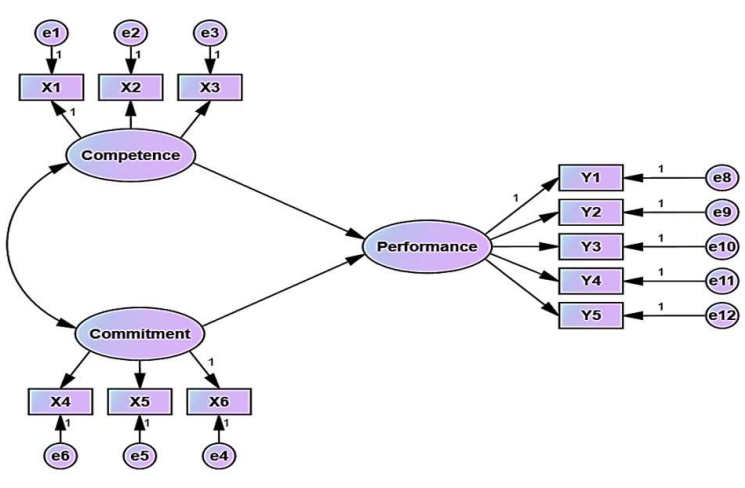

Figure 1: Multivariate Research Model.

\begin{tabular}{|l|l|}
\hline Variable & Indicator \\
\hline Competence [12] & Intellectual (X1) \\
\hline & Emotional (X2) \\
\hline & Social (X3) \\
\hline $\begin{array}{l}\text { Commitment } \\
\text { 21] }\end{array}$ & Affective Organizational (X4) \\
\hline & $\begin{array}{l}\text { Continuance Organizational } \\
\text { (X5) }\end{array}$ \\
\hline & Normative Organizational (X6) \\
\hline Performance [22] & Quality (Y1) \\
\hline & Quantity (Y2) \\
\hline & Punctuality (Y3) \\
\hline & Effectiveness (Y4) \\
\hline & Independence (Y5) \\
\hline
\end{tabular}

Table 1: Indicator of the Research Variable.

Population and Samples: The population is a zone of generalization that covers objects or subjects that have specific attributes and characteristics set by researchers to be explored and then drawn to conclusions. The population of this study was all agricultural extension agents totaling 690 people. The sample in this study was by cluster sampling technique or cluster random sampling. This technique uses when the population does not consist of persons but consists of individual groups or clusters [23]. Regional sampling technique is used to determine the sample if the object to be studied or the data source is comprehensive. Then according to Hair [24], it gives suggestions about sample size for multivariate research by considering the number of indicators of variables, namely $5-10 \mathrm{x}$ indicators. From the number of indicators, as many as 11 obtained the number of samples as many as 110 samples that will use as respondents.

Research Instrument: This study uses a questionnaire as a research instrument. Measurement of variables using a Likert Scale, with the characteristics of the Likert Scale is most suitable for use in research design where respondents in responding to questionnaires conducted personally (self-administered), use personal interviewers or use online methods in 
collecting data so that respondents are free in terms of time in responding to questionnaires, The Likert scale generally uses five description scales such as "strongly agree", "agree", "disagree", "disagree" and, "strongly disagree". The five scales are given weights 1 to 5 . The data obtained in this study needs to be analyzed further so that the right conclusions can be drawn, then the validity in this study is primarily determined by the measuring instruments of the variables to be studied.

Test Validity of Instruments: Used to measure whether valid or valid questionnaires. A questionnaire is said to be valid if a question or statement on the questionnaire can reveal something measured by the questionnaire. The results of the validity analysis aimed by comparing r-count with r-table, while the value of r-count can see from corrected item-total correlation through the analysis of the IBM SPSS Program [25].

Instrument Reliability Test: Used to determine the extent to which a measuring instrument can be used, trusted, and used to examine an object. In this study, a reliability test of the questionnaire was conducted to find out the extent to which the questionnaire is reliable and reliable. The technique used to test reliability is Cronbach alpha. The questionnaire is said to be reliable if the coefficient obtained is $>0.60$. The results obtained from the reliability test on the questionnaire on each variable [25].

Data Collection: This research was conducted directly in the field to obtain data from research objects. In this study, data collection was carried out by survey method, namely by distributing questionnaires directly to respondents, namely agricultural extension staff in Banten Province.

Data Analysis: In this study, data analysis used multiple linear regression with IBM SPSS Program version 22.0. Multiple regression is a regression or prediction model that involves more than one independent variable or predictor to determine the effect of one or more independent variables on one dependent variable. The purpose of this analysis is to find out the magnitude of the influence of competence, commitment to employee performance.

\section{Result and Discussions}

Normality and Heteroscedasticity Test: The normality test can see through the Normal P-P Plot graph. If the points have followed a straight line, it can be said that the residual had followed the normal distribution. If the points are scattered or far from a straight line, then residuals are said to follow an abnormal distribution. Heteroscedasticity is one of the factors that causes a simple linear regression model to be inefficient and accurate, and it also results in the use of the maximum likelihood method in estimating the regression parameters (coefficients). This method is a non-formal method but can use as an indicator of heteroscedasticity. If there is no clear pattern (spread points), there is no heteroscedasticity.

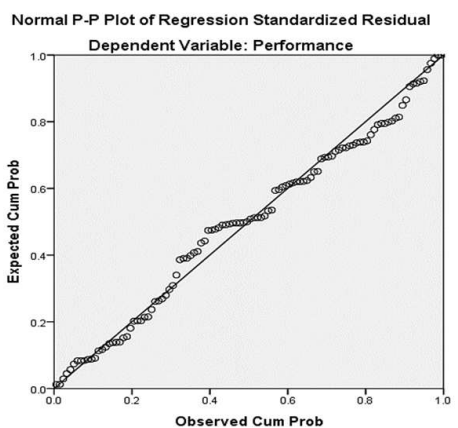

(a)

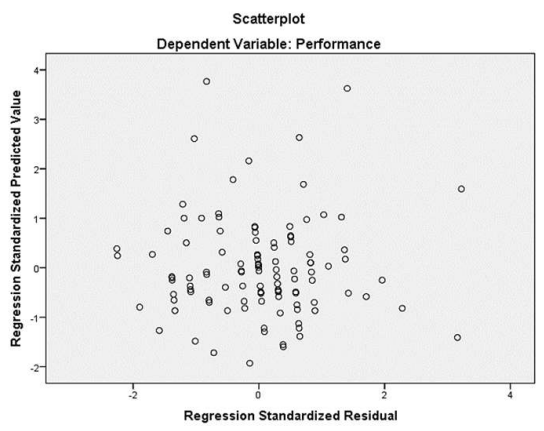

(b)

Figure 2: (a) Normal P-P Plot Regression Standardized Residual; (b) Scatterplot for Heteroscedasticity Test

Normal P-P Graph, the plot in Figure 2a, shows that scattered points follow a straight line so that the distribution pattern is said to be normal. Then it can be concluded that the data used in this study meets the classical assumptions. Then for Figure $2 b$ above is the result of the heteroscedasticity test. From the graph, it can see that the points spread out and did not form a specific pattern, and that point was above and below number 0 on the Y-axis. So, it can be concluded that there was no or no heteroscedasticity in this study.

The Multicollinearity Test: aims to determine the relationship between the independent variables having multi-correlation problems (symptoms of multicollinearity) or not. The presence or absence of symptoms of multicollinearity on tolerance values and VIF. The regression that is free from multicollinearity is one that has a value of less than 10, VIF that exceeds ten then it is said that collinearity occurs and has a tolerance value close to 1 if it is less than 0.10 , it is said to occur collinearity. From the results of the analysis with the IBM SPSS Program, obtained the VIF value of the competency variable, commitment to each performance 1.376 for competence, 1,621 for commitment. Then for tolerance value obtained 0.671 for competence, 0.655 for commitment. Of the two variables, the value of VIF is still below 10 . The tolerance value of the three variables, the value is still above 0.10 . Then it can be concluded that there is no multicollinearity between independent variables. 
The Coefficient of Determination: is used to determine the extent to which the accuracy or compatibility of the regression lines formed in representing groups of observational data. The higher the value of R-Square (close to 1), then the efficiency is said to be better. From Table 2, the R-Square value is 0.836 or $83.60 \%$, which means that the relationship between the independent variable and the dependent variable is $83.60 \%$. This relationship will be perfect (100\%) or close if there are other independent variables included in the model. In other words, organizational competency and commitment have a joint influence of around $83.60 \%$ on employee performance, while the remaining $16.40 \%$ influenced by other variables, such as leadership, motivation, environment, career development, and others.

\begin{tabular}{|c|c|c|c|c|c|c|}
\hline & & & t-count & Sig. & Estimate & R-Square \\
\hline Competence & $\rightarrow$ & Performance & 2.516 & 0.012 & 0.742 & \multirow{2}{*}{0.836} \\
\hline Commitment & $\rightarrow$ & Performance & 2.593 & 0.008 & 0.729 & \\
\hline
\end{tabular}

Table 2: Standard Regression Coefficient and Determination Coefficient (R-Square)

Table 2 shows that there is a significant effect of competency variables on performance. It can see from the values obtained, which tend to be high. It also occurs in commitment variables which have a positive and significant effect on performance. These results are precise that the two factors, namely competence and commitment, are needed by employees or employees to improve performance at work. It is shown in the research conducted by Mathiew and Zajac [26], which shows that organizational commitment is a relationship between individuals and organizations so that individuals feel that having an organization can thus improve managerial performance. Boyatzis [27], then said that competency is needed to carry out specific roles to produce satisfactory work performance. Research conducted by McClelland [28], shows that competence successfully predicts the performance or performance of individuals in work.

Competence is one of the main variables that consistently and stably contributes to commitment. From these results, it can also be interpreted that an increase in competence will make a meaningful contribution to commitment. According to Dhladhla [29], employee job satisfaction is one of the crucial issues for all organizations, either public organizations or private organizations, both in developing countries and in developed countries. Employees who are satisfied with their work will increase their commitment and will ultimately increase the productivity and effectiveness of the organization. Whereas according to the analysis Sichtmann and von Selasinsky [30], competencies generated from training activities, with training, employees will understand their functions and tasks, and this will ultimately have a positive influence on employee commitment. According to Sahoo, Behera, and Tripathy [31], mentioning that employees who are committed to their work and career tend to stay, be satisfied with work, and have motivation in completing work tasks.

Employees who have high organizational commitment also have a positive outlook and will do their best for the benefit of the organization. According to McClelland [28], skills and knowledge have an essential role in one's success, but the other four competencies play a much more significant role. Competence is a crucial determining factor for someone in producing excellent performance. In a typical situation, competence is a crucial factor determining the success of an organization. Organizational commitment is an important variable that must be considered, given the high costs associated with turnover. It has defined as a psychological link between employees and their organizations, which minimizes the possibility that employees will voluntarily leave the organization. Commitment is related to attachment, identification, and involvement of employees with organizations [14]. Organizational commitment is positively related to job performance, organizational citizenship behavior, and job satisfaction [32,33]. Moreover, Lum [30], found that organizational commitment had a direct impact on the intention to leave their position

Boyatzis and Ron research [34], shows that to get the right personality in the organization will not be easy because what is needed is not only the person who is brilliant or highly educated but, there are mental factors that underlie the connection between the individual and his organization. These subjective factors influence a person's ability in the group, including the ability to regulate themselves, ambition, enthusiasm, organizing emotions in themselves, and doing calm thoughts without being carried away by feelings. How far the commitment of employees to the organization determines the organization in achieving its objectives. Even some organizations dare to include elements of commitment as one of the conditions for occupying positions or positions offered in job advertisements, but it is not uncommon for organizational actors do not understand the meaning of these commitments.

Steers and Porter [35], define organizational loyalty as identification (trust in organizational values), job participation (willingness to try as well as possible for the profit of the organization), and loyalty (the desire to remain a member of the organization) expressed by an worker towards organization. Organizational loyalty means more than just official membership because it includes the attitude of liking and having an organization and the willingness to seek a high level of effort for the interests of the organization included components of loyalty to the group, involvement in work, and identification of organizational values and objectives. Understandably, employee commitment to the organization is a relationship between individual employees and work organizations, where employees have confidence and trust in the values and goals of work organizations, there is a willingness to use their business seriously for the benefit of work organizations and have strong desires to remain part of a work organization. In this case, the individual identifies himself in a particular organization where the individual works and hopes to become a member of a work organization in order to realize the goals of the work organization. Employees with high organizational commitment will work with dedication 
because employees who have high commitment assume that the critical thing that must achieve is the achievement of tasks in the organization. It makes employees have the desire to provide personnel and responsibilities that further support the welfare and success of the organization in which they work. Conversely, employees with low levels of commitment will cause violations of rules such as attendance to end up in dismissal, then resignation. In the world of work, employee commitment to the organization is very important so that some organizations dare to incorporate elements of commitment as one of the requirements to hold positions offered in job advertisements.

In assessing performance, the nature and results of the research will depend a lot on how human resources are viewed and treated within the organization. If the organization believes that people do not work unless they are closely monitored and controlled, performance appraisals tend to be carried out in the form of confidential reports. However, if people believe that each has potential and strengths and that human ability can be sharpened in a healthy climate, the organization will develop a work assessment system that seeks to recognize, sharpen, develop and utilize the potential and capabilities of its employees [36].

Several studies to examine the relationship between participation and managerial performance were carried out using intervening variables. Brownell and Mc Innes [37], used intervening motivational variables to test the relationship between participation and performance. The results showed that motivation and participation had a direct relationship with performance. The results of these studies are different from previous studies conducted by Merchant [38], who found a positive relationship between motivation and participation. Based on the results of this study, Brownell and Mc Innes [37], argue that future research should test performance for participation, not through motivation.

The participation of someone to participate is inseparable from the motivation of each employee. Regarding their participation in the formulation of activities, employees are motivated to participate in the formulation of activities because of the concern for the organization and a sense of belonging to the organization. The leaders of the employees justified the reason. It is in line with what is felt by employees who claim that there is no commitment because there is no feeling that having an organization is an obstacle when participating [39]. Besides, communication also plays an essential role in generating employee participation to participate in the formulation of activities. Improving employee performance is the primary concern of every company/organization in carrying out its business activities. Employees with satisfying performance are precious company assets. Employees are precious company human resources and can help in achieving company goals.

\section{Conclusions}

Competence and commitment can be measured, so an assessment is needed. Evaluation in the organization is critical because it will be useful to know the effectiveness of the organization so that the goals of the organization will achieve. Performance is the real behavior displayed by everyone as the work performance produced by employees following their role in the company. Actual behavior posted by employees is influenced by various factors that help shape a person's behavior (employees), which then reflected in the actions and behavior in doing work. The problem is how to create Human Resources that can produce optimal performance so that organizational goals can achieve. Employee performance will not be separated by factors that can affect a person's performance. Considering the problem is very complex, the parties involved in the company must be careful in observing the available resources. Therefore, to improve the performance of agricultural extension agents in Indonesia, it is necessary to carry out various strategic breakthroughs that can streamline competence and increase commitment with the use of digital-based media that can be easily accessed and as a source of information.

\section{References}

1. Becker B, Gerhart B. The impact of human resource management on organizational performance: Progress and prospects. Acad Manag J. 1996;39(4):779-801.

2. Huselid MA. The impact of human resource management practices on turnover, productivity, and corporate financial performance. Acad Manag J. 1995;38(3):635-72.

3. Schneider B, Bowen DE. The service organization: Human resources management is crucial. Organ Dyn. 1993;21(4):39-52.

4. Delaney JT, Huselid MA. The impact of human resource management practices on perceptions of organizational performance. Acad Manag J. 1996;39(4):949-69.

5. Armstrong M. A handbook of human resource management practice. Kogan Page Publishers; 2006.

6. Noe RA, Hollenbeck JR, Gerhart B, Wright PM. Human resource management: Gaining a competitive advantage. McGraw-Hill Education New York, NY; 2017.

7. Shields J, Brown M, Kaine S, Dolle-Samuel C, North-Samardzic A, McLean P, et al. Managing employee performance \& reward: Concepts, practices, strategies. Cambridge University Press; 2015.

8. Cote S, Miners CTH. Emotional intelligence, cognitive intelligence, and job performance. Adm Sci Q. 2006;51(1):128.

9. Boyatzis R, Boyatzis RE. Competencies as a behavioral approach to emotional intelligence. J Manag Dev. 2009;

10. Boyatzis R, Boyatzis RE. Competencies in the 21st century. J Manag Dev. 2008;

11. Goleman D. Emotional intelligence. Bantam; 2006. 
12. Spencer LM, Spencer PSM. Competence at Work models for superior performance. John Wiley \& Sons; 2008.

13. Meyer JP, Paunonen S V, Gellatly IR, Goffin RD, Jackson DN. Organizational commitment and job performance: It's the nature of the commitment that counts. J Appl Psychol. 1989;74(1):152.

14. Meyer JP, Allen NJ. A three-component conceptualization of organizational commitment. Hum Resour Manag Rev. 1991;1(1):61-89.

15. Olson-Buchanan JB, Boswell WR. The role of employee loyalty and formality in voicing discontent. J Appl Psychol. 2002;87(6):1167.

16. Steers RM. Antecedents and outcomes of organizational commitment. Adm Sci Q. 1977;46-56.

17. Mathis RL, Jackson JH. Personnel/human resource management. West Publishing Company St. Paul, MN; 1991.

18. Podsakoff PM, Ahearne M, MacKenzie SB. Organizational citizenship behavior and the quantity and quality of work group performance. J Appl Psychol. 1997;82(2):262.

19. Vroom VH. Work and motivation. Vol. 54. Wiley New York; 1964.

20. McClelland DC. Achievement motivation in relation to achievement-related recall, performance, and urine flow, a marker associated with release of vasopressin. Motiv Emot. 1995;19(1):59-76.

21. Robbins SP, Judge TA. Organizational behavior . Upper Saddle. New Jersey: Prentice Hall; 2003.

22. Bernadin H. Effective performance management. Perform Apprais State art Pract San Fr Jossey-Bass. 1998;

23. Bordens, Kenneth S., Abbott, Bruce B. Research Design and Methods : A Process Approach. 9th ed. New York: McGraw-Hill Education; 2014. 610 p.

24. Hair JF, Black WC, Babin BJ, Anderson RE. Multivariate Data Analysis. 7th ed. Pearson New International Edition. Harlow, England: Pearson New International Edition; 2014.

25. George D, Mallery P. IBM SPSS Statistics 23 Step by Step: A Simple Guide and Reference. 14th ed. New York, United States: Routledge; 2016.

26. Mathieu JE, Zajac DM. A review and meta-analysis of the antecedents, correlates, and consequences of organizational commitment. Psychol Bull. 1990;108(2):171.

27. Boyatzis RE. The competent manager: A model for effective performance. John Wiley \& Sons; 1982.

28. McClelland DC. Testing for competence rather than for" intelligence.". Am Psychol. 1973;28(1):1.

29. Dhladhla TJ. The Influence of Leader Behaviour, Psychological Empowerment, Job Satisfaction, and Organizational Commitment on Turnover Intention. 2011;(March).

30. Sichtmann C, von Selasinsky M. Exporting Services Successfully: Antecedents and Performance Implications of Customer Relationships. J Int Mark. 2010;18(1):86-108.

31. Sahoo CK, Behera N, Tripathy SK. Employee Empowerment and Individual Commitment: an Analysis From Integrative Review of Research. Employ Relations. 2010;10(1):40-56.

32. Meyer JP, Allen NJ. Commitment in the workplace: Theory, research, and application. Sage; 1997.

33. Allen NJ, Meyer JP. Affective, continuance, and normative commitment to the organization: An examination of construct validity. J Vocat Behav. 1996;49(3):252-76.

34. Boyatzis RE. Unleashing the power of self-directed learning. Chang W we Manag Chang. 2002;13-32.

35. Steers RM, Porter LW. Employee commitment to organizations. Motiv Work Behav. 1983;99:441-51.

36. Rao TV. Performance Management and Appraisal Systems: HR tools for global competitiveness. SAGE Publications India; 2004.

37. Brownell P, McInnes M. Budgetary participation, motivation, and managerial performance. Account Rev. 1986;587600 .

38. Merchant KA. The design of the corporate budgeting system: influences on managerial behavior and performance. Account Rev. 1981;813-29.

39. Darhamsyah. Environmental Governance Urban: Public Participation and Sustainable Development. Int J Environ Eng Educ. 2019;1(1):17-24. 